\title{
MENINGKATKAN HA SIL BELAJAR SISWA IPS MELALUI PENERAPAN MODEL PEMBELAJARAN KOOPERATIF TIPE JIGSAW DI KELAS VI SDN 1 BATUGANDA
}

\author{
Hasmunawira $^{1)}$, I Ketut Suardika ${ }^{2)}$ \\ 1) SDN 1 Batuganda, Kolaka, Indonesia \\ ${ }^{2)}$ Jurusan PGSD, Universitas Halu Oleo, Kendari, Indonesia \\ email: hasmunawiramira@gmail.com
}

\begin{abstract}
Abstrak: Tujuan dari penelitian ini adalah untuk meningkatkan hasil belajar IPS siswa melalui penerapan model pembelajaran kooperatif tipe jigsaw di Kelas VI SD Negeri 1 Batuganda. Prosedur penelitian ini meliputi: perencanaan, pelaksanaan tindakan, observasi dan evaluasi, serta refleksi. Teknik pengumpulan data menggunakan lembar observasi aktivitas guru, dan evaluasi tes siklus. Teknik analisis data menggunakan analisis deskriptif. Indikator keberhasilan dalam penelitian ini terdiri dua yaitu dari segi proses dan hasil. Dilihat dari segi proses, tindakan dikatakan berhasil apabila minimal $80 \%$ proses pelaksanaan pembelajaran terlaksana dengan baik. Dilihat dari segi hasil, tindakan dikatakan berhasil apabila minimal $80 \%$ dari jumlah siswa mencapai nilai $\geq 70$. Hasil penelitian pada siklus I terdapat 17 siswa yang telah mencapai nilai $\geq 70$ dengan ketuntasan sebesar 73,9\% dan yang tidak tuntas mencapai $26,1 \%$. Aktivitas mengajar guru siklus I pertemuan pertama sebesar $66,67 \%$ dan pertemuan kedua $77,78 \%$. Aktivitas belajar siswa siklus I pertemuan pertama sebesar $66,67 \%$ dan pertemuan kedua $77,78 \%$. Siklus II terdapat 21 siswa telah mencapai nilai $\geq 70$ dengan ketuntasan sebesar 91,3\%. Aktivitas mengajar guru siklus I pertemuan pertama sebesar $88,89 \%$ dan pertemuan kedua $100 \%$. Aktivitas belajar siswa siklus I pertemuan pertama sebesar $88,89 \%$ dan pertemuan kedua $100 \%$.
\end{abstract}

Kata kunci: Model Jigsaw; hasil belajar

\section{IMPROVING THE STUDENT'S LEARNING OUTCOMES OF IPS LESSON THROUGH THE IMPLEMENTATION OF THE JIGSAW TYPE COOPERATIVE LEARNING MODEL IN CLASS VI SDN 1 BATUGANDA}

\footnotetext{
Abstract: This research aimed to improve students' social studies learning outcomes through the application of the jigsaw cooperative learning model in Class VI SD Negeri 1 Batuganda. This research procedure includes: planning, implementing actions, observation and evaluation, and reflection. Data collection techniques used teacher activity observation sheets, and cycle test evaluations. The data analysis technique used descriptive analysis.There are two indicators of success in this study, namely in terms of process and outcome. In terms of the process, the action is said to be successful if at least $80 \%$ of the learning process is carried out well. In terms of results, the action is said to be successful if at least $80 \%$ of the total number of students reaches a value of $\geq 70$. The results of the research in the first cycle there were 17 students who had reached a value of $\geq 70$ with completeness of $73.9 \%$ and those who did not complete reached $26.1 \%$. The teaching activity of the teacher in the first cycle of the first meeting was $66.67 \%$ and the second meeting was $77.78 \%$. Student learning activities in the first cycle of the first meeting was $66.67 \%$ and the second meeting was $77.78 \%$. In cycle II, there were 21 students who had achieved a value of $\geq 70$ with completeness of 91.3\%. The teaching activity of the teacher in the first cycle of the first meeting was $88.89 \%$ and the second meeting was $100 \%$. The learning activities of students in the first cycle of the first meeting were $88.89 \%$ and the second meeting was $100 \%$. Keywords: Jigsaw Models; learning outcomes
} 


\section{Pendahuluan}

Pendidikan merupakan bidang utama dalam pembangunan sumber daya manusia yang berkualitas tinggi dan berpotensi untuk dapat membangun bangsa dan negara yang lebih sejahtera. Upaya untuk mengembangkan sumber daya manusia dilakukan melalui pendidikan khususnya melalui perbaikan proses pembelajaran di sekolah. Dalam proses pembelajaran, guru sangat memiliki peranan yang pling penting. Oleh karena pendidikan membutuhkan guru profesional untuk membelajarkan dan melibatkan siswa dalam proses pembelajaran agar tujuan pembelajaran dapat tercapai secara efektif. Guru profesional hendaknya mampu membantu dan mengarahkan peserta didik untuk mengalami proses pembelajaran sesuai dengan minat, bakat, potensi, perkembangan fisik, dan psikologisnya. Dalam hal ini dibutuhkan sosok guru yang mampu memahami potensi peserta didik dengan baik sehingga mampu melayani peserta didik dengan baik sehingga mampu melayani peserta didik sesuai dengan kebutuhan dan karakteristiknya.

Salah satu realitas dalam pendidikan kita yang sukar diingkari dewasa ini adalah lemahnya peran guru dalam proses pengembangan potensi siswa. Fenomena seperti ini sudah merupakan tradisi di sekolah, khususnya pada pembelajaran IPS di Sekolah Dasar (SD). Guru dianggap sebagai sumber belajar yang paling benar, sedangkan posisi siswa sebagai pendengar ceramah guru. Akibatnya, proses pembelajaran cenderung membosankan dan menjadikan siswa malas belajar. Sikap siswa yang pasif tersebut ternyata tidak hanya terjadi pada mata pelajaran tertentu saja, tetapi pada hampir semua mata pelajaran termasuk IPS. Menurut Mana'a, dkk (2014, p.2) Ilmu Pengetahuan Sosial (IPS) merupakan salah satu cabang ilmu yang dipelajari sejak kita mengenal dunia dan tidak akan pernah berakhir untuk dipelajari,karena IPS merupakan ilmu yang sangat dekat dengan keseharian kita sehingga baik secara formal maupun informal kita akan tetap mempelajarinya.

Fenomena seperti yang dikemukakan tersebut di atas terjadi pada SD Negeri 1 Batuganda. Pada tanggal 30 Mei 2016 melalui wawancara singkat dengan guru kelas VI SDN 1 Batuganda yang menunjukan data nilai siswa hasil ulangan harian yang masih rendah pada bidang studi IPS materi benua yang ada di dunia. Nilai rata-rata hasil ulangan harian siswa materi benua yang ada di dunia pada semester ganjil pada tahun pelajaran 2015/2016 adalah 65. Persentase ketuntasan klasikal yang diperoleh siswa belum mencapai standar KKM yang ditetapkan sekolah yaitu minimal $80 \%$ siswa memperoleh nilai $\geq 65$.

Rendahnya hasil belajar siswa terjadi karena dalam pembelajaran, guru hanya menerapkan pembelajaran konvensional yaitu hanya menggunakan metode ceramah atau metode tanya jawab. Dalam pembelajaran, siswa tidak dilibatkan secara aktif. Siswa tidak dapat membuat hubungan antara apa yang mereka pelajari dan bagaimana pengetahuan tersebut akan diaplikasikan, siswa mengalami kesulitan memahami konsep akademik dalam pembelajaran dengan metode yang tidak tepat dan monoton. Akibatnya pembelajaran berlangsung tidak efektif sehingga siswa kurang termotivasi untuk belajar yang pada akhirnya daya serap siswa terhadap materi pelajaran yang disampaikan juga semakin berkurang sehingga hasil belajar siswa juga rendah.

Upaya meningkatkan hasil belajar siswa merupakan salah satu tugas dan tanggungjawab seorang guru atau tenaga pendidik yang profesional. Salah satu upaya untuk meningkatkan kualitas pembelajaran seorang guru adalah memperbaiki pola pembelajaran dengan menerapkan pendekatan atau model belajar yang dinilai efektif dan efisien oleh guru untuk diterapkan di kelas. Oleh karena itu guru hendaknya mampu mencari strategi yang mampu membelajarkan dan melibatkan siswa dalam proses pembelajaran, agar tujuan pembelajaran dapat tercapai secara efektif dan efisien sehingga hasil belajar siswa dapat ditingkatkan. 
Permasalahan yang terjadi seperti di atas, dapat diatasi dengan menerapkan model pembelajaran yang tepat dan sesuai dengan karateristik siswa dan muatan materi pembelajaran agar siswa lebih tertarik dan termotivasi sehinga pembelajaran dapat berlangsung secara efektif dan pada akhirnya dapat memperbaiki atau meningkatkan hasil belajar siswa. Model pembelajaran yang bisa diterapkan adalah model pembelajaran kooperatif tipe jigsaw. Alasan peneliti memilih model pembelajaran kooperatif tipe jigsaw dalam pembelajaran IPS karena model pembelajaran kooperatif tipe jigsaw menuntut siswa merekontruksi pengatahuan dalam mempelajari suatu subjek serta menyiapkan siswa untuk berpikir kritis dalam menyelesaikan suatu permasalahan dengan mendiskusikannya secara kelompok, sehingga siswa tidak hanya mampu untuk mendapatkan suatu konsep dengan membangun pengetahuannya sendiri tetapi juga untuk berinteraksi dengan guru melalui pertanyaan-pertanyaan maupun dengan siswa lain melalui kerja kelompok. Selain itu diharapkan siswa akan termotivasi untuk belajar dan memiliki minat serta perhatian terhadap pelajaran karena siswa tidak hanya bertugas mendengarkan dan mencatat saja. Dalam model pembelajaran ini, siswa bergabung dalam kelompok kecil, kemudian setiap individu diberikan permasalahan dan setelah memahami permasalahan, mereka bergabung dengan siswa dari kelompok lain yang mendapatkan permasalahan yang sama kedalam satu kelompok yang disebut kelompok ahli (Purwati 2015, p. 178). Kelas dibagi menjadi beberapa tim yang anggotanya terdiri dari 5 atau 6 siswa dengan karakteristik yang heterogen (Bindiab, dkk. 2013, p. 109).

Berdasarkan uraian di atas, maka penulis tertarik untuk memperbaiki cara mengajar guru untuk meningkatkan hasil belajar siswa yaitu dengan melakukan penelitian yang berjudul "Meningkatkan Hasil Belajar Siswa pada Materi Benua yang ada di dunia Mata Pelajaran IPS Melalui Penerapan Model Pembelajaran Kooperatif Tipe Jigsaw di Kelas VI SDN 1 Batuganda Kabupaten Kolaka Utara”.

Hasil penelitian yang dilakukan oleh Romianti (2012) dengan judul penelitian Meningkatkan Hasil Belajar Ilmu Pengetahuan Sosial (IPS) Melalui Penerapan Model Pembelajaran Kooperatif Tipe Jigsaw pada siswa Kelas VI SDN 17 Napabalano Kecamatan Towea Kabupaten Muna. Hasil penelitian ini menunjukkan bahwa aktivitas siswa dalam proses pembelajaran dengan penerapan model pembelajaran kooperatif tipe jigsaw mengalami peningkatan. Pada siklus I aktivitas belajar siswa rata-rata 53,85\%. Pada siklus II rata-rata aktivitas belajar siswa $84,62 \%$. Persentase ketuntasan belajar siswa pada siklus I siswa yang tuntas adalah $73,08 \%$ (19 orang) sedangkan pada siklus II siswa yang tuntas mencapai $88,46 \%$ (23 orang).

Hasil penelitian yang dilakukan oleh Sulasmi (2011) dengan judul Penerapan Model Pembelajaran Kooperatif Tipe Jigsaw untuk Meningkatkan Hasil Belajar IPS Siswa pada Materi Sumber Daya Alam di Kelas VI SDN 15 Katobu Kabupaten Muna. Pada siklus I ketuntasan hasil belajar siswa mencapai 55\%. Pada siklus II ketuntasan hasil belajar siswa mencapai 90\%. Berdasarkan hasil penelitian yang dilakukan oleh disimpulkan bahwa Hasil Belajar Siswa pada Materi Sumber Daya Alam dapat ditingkatkan melalui Penerapan Model Pembelajaran Kooperatif Tipe Jigsaw di Kelas VI SDN 15 Katobu Kabupaten Muna.

Model pembelajaran kooperatif tipe jigsaww dirancang secara matang dan dilaksanakan secara tepat diharapkan dapat mendorong siswa lebih dapat meningkatkan persiapan dalam menerima pelajaran. Peningkatan motivasi belajar siswa juga diharapkan membawa dampak positif yaitu peningkatan hasil belajar siswa.

Masalah dalam penelitian adalah apakah penerapan model pembelajaran kooperatif tipe jigsaw dapat meningkatkan hasil belajar IPS siswa di Kelas VI SD Negeri 1 Batuganda Tujuan penelitian adalah untuk meningkatkan hasil belajar IPS siswa melalui penerapan 
model pembelajaran kooperatif tipe jigsaw di Kelas VI SD Negeri 1 Batuganda. Penelitian ini diharapkan dapat memberikan manfaat bagi guru, siswa, sekolah dan penelitian lainnya.

\section{Metode}

Jenis penelitian ini adalah penelitian tindakan kelas (PTK). Penelitian ini adalah suatu bentuk kajian yang bersifat reflektif oleh pelaku tindakan. Penelitian ini dilaksanakan pada semester ganjil tahun pelajaran 2016/2017 bertempat di SD Negeri 1 Batuganda Kabupaten Kolaka Utara. Subjek penelitian ini adalah guru dan siswa Kelas VI SD Negeri 1 Batuganda yang terdaftar pada semester ganjil tahun pelajaran 2016/2017 berjumlah 23 orang yang terdiri dari 13 siswa perempuan dan 10 siswa laki-laki. Faktor yang diteliti dalam penelitian ini adalah 1) faktor siswa, 2) Faktor guru dan faktor 3) hasil belajar. Penelitian Tindakan Kelas ini dilaksanakan dalam 2 (dua) siklus. Adapun prosedur penelitian tindakan ini meliputi: (1) Perencanaan, (2) Pelaksanaan Tindakan, (3) Observasi dan Evaluasi, dan (4) Refleksi dalam setiap siklus. Data dalam penelitian ini adalah data kuantitatif diperoleh dari hasil belajar IPS siswa Kelas VI SD Negeri 1 Batuganda dan data kualitatifdiperoleh dari hasil observasi aktivitas siswa selama mengikuti proses model pembelajaran kooperatif tipe jigsaw yang diterapkan oleh guru dan aktivitas guru selama pembelajaran IPS menggunakan model pembelajaran kooperatif tipe jigsaw.

Analisis data dalam penelitian ini adalah menggunakan statistik deskriptif untuk menghitung nilai siswa, rata-rata nilai siswa, ketuntasan belajar, keberhasilan aktivitas mengajar guru dan keberhasilan aktvitas belajar siswa.

Indikator keberhasilan penelitian terdiri atas 1) Proses pembelajaran dikatakan berhasil jika persentase keberhasilan aktivitas mengajar guru dan persentase aktivitas belajar siswa mencapai $80 \%$ pembelajaran terlaksana sesuai dengan RPP, 2) Ketuntasan hasil belajar siswa tercapai jika minimal $80 \%$ siswa memperoleh nilai minimal 70.

\section{Hasil}

\section{Hasil Belajar Siswa}

Hasil analisis penelitian pada siklus I terdapat 17 siswa yang telah mencapai nilai $\geq 70$ dengan ketuntasan sebesar 73,9\% dan yang tidak tuntas mencapai $26,1 \%$. Siklus II terdapat 21 siswa telah mencapai nilai $\geq 70$ dengan ketuntasan sebesar $91,3 \%$. Untuk lebih jelasnya peningkatan hasil belajar dapat dilihat pada Grafik 1 berikut.

Gambar 1. Grafik Hasil Belajar Siswa Siklus I dan Siklus II 


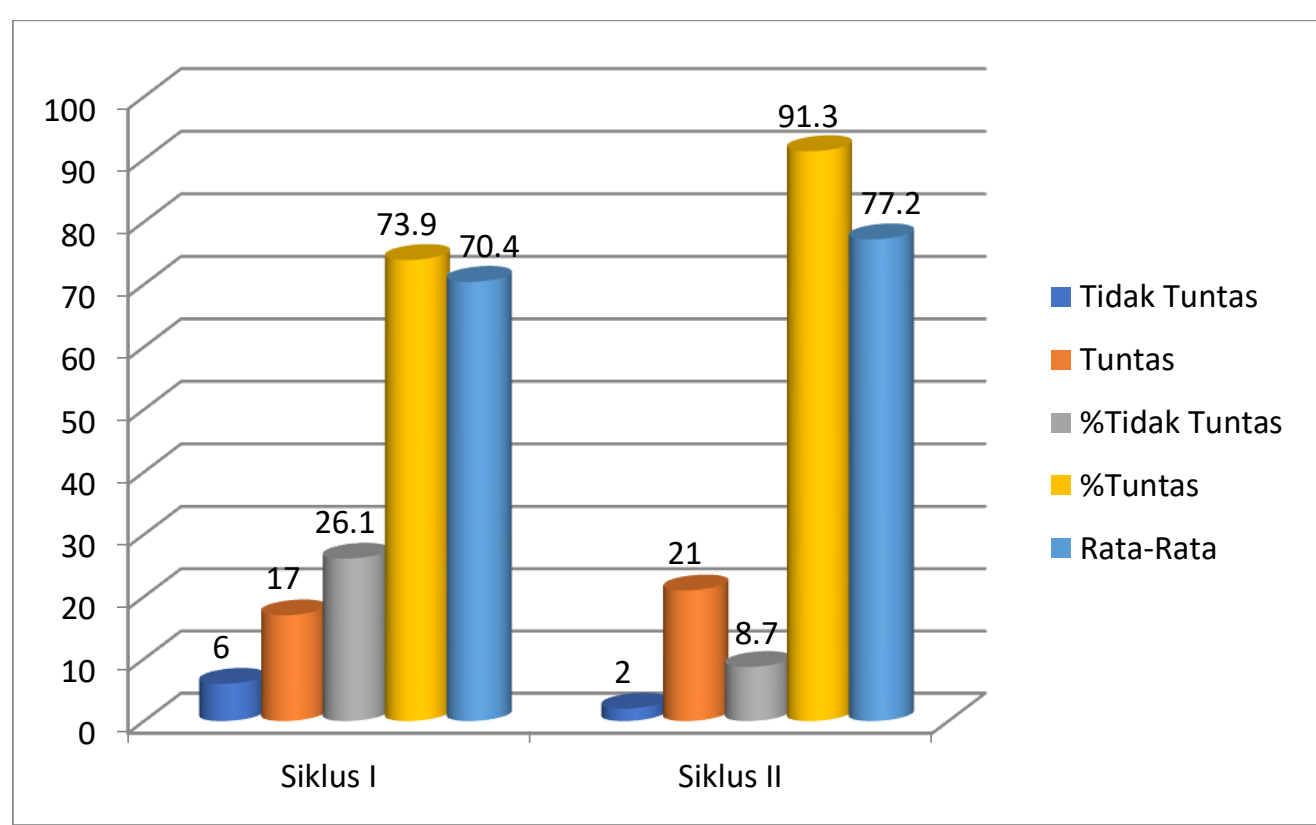

Berdasarkan Gambar 1. di atas, menunjukkan bahwa pada siklsu I persentase ketuntasan hasil belajar siswa sebesar $73,9 \%$. Pada siklus II persentase ketuntasan ahsil belajar siswa meningkat sebesar 17,4\% menjadi 91,3\%. Ketuntasan belajar siswa mengindikasikan bahwa indikator keberhasilan penelitian yang ditetapkan telah tercapai.

\section{Aktivitas Mengajar Guru}

Hasil analisis penelitian pada siklus I aktivitas mengajar guru siklus I pertemuan pertama sebesar $66,67 \%$ dan pertemuan kedua $77,78 \%$. Siklus II aktivitas mengajar guru siklus I pertemuan pertama sebesar $88,89 \%$ dan pertemuan kedua $100 \%$.

\section{Aktivitas Belajar Siswa}

Hasil analisis penelitian pada siklus I aktivitas belajar siswa siklus I pertemuan pertama sebesar $66,67 \%$ dan pertemuan kedua $77,78 \%$. Siklus aktivitas belajar siswa siklus I pertemuan pertama sebesar $88,89 \%$ dan pertemuan kedua $100 \%$.

\section{Pembahasan}

\section{Hasil Belajar Siswa}

Rendahnya persentase ketuntasan hasil belajar siswa siklus I menunjukan indikator keberhasilan siklus I sebesar $80 \%$ belum tercapai, sehingga dilakukan perbaikan-perbaikan utamanya kinerja guru dalam menumbuhkan minat dan motivasi belajar siswa serta dalam membimbing siswa. Selain itu ketidaktuntasan beberapa siswa tersebut diakibatkan kurangnya perhatian siswa dalam mengikuti pelajaran serta kurangnya fasilitas pembelajaran (buku) yang tersedia. Hal ini sejalan dengan pendapat yang dikemukakan oleh Slameto (2003, p.32) bahwa dalam usaha mencapai tujuan belajar perlu diciptakan kondisi belajar yang kondusif agar terjadi proses belajar yang optimal dan hasil belajar yang memuaskan. Menurut Ulfah, dkk. (2016, p.1610) mengemukakan bahwa hasil belajar merupakan hasil keberhasilan dari interaksi belajar mengajar yang mencakup bidang kognitif, afektif, dan psikomotorik yang ditunjukkan dengan perubahan tingkah laku yang khas. Menurut Untari (2013, p.79) pengorganisasian proses belajar mengajar dikelas dengan strategi pembelajaran yang tepat adalah salah satu hal yang harus benar-benar dipahami oleh guru selaku pendidik untuk meningkatkan aktivitas sekaligus hasil belajar siswa. Senada dengan Kurniyati (2016, p.326) menjelaskan bahwa keberhasilan proses kegiatan belajar mengajar pada pembelajaran IPS 
dapat diukur dari keberhasilan siswa yang dilihat dari tingkat penguasaan materi serta hasil belajar siswa.

Persentase ketuntasan hasil belajar siswa pada siklus II telah mencapai indikator kinerja yang ditetapkan yaitu minimal $80 \%$ siswa memeproleh nilai 70 . Meskipun masih ada 2 orang $(8,7 \%)$ siswa masih memiliki hasil belajar di bawah 70 , akan tetapi mereka sudah memberikan penghargaan dan sikap yang positif pada saat model pembelajaran kooperatif tipe Jigsaw diterapkan. Menurut Alfazr, dkk. (2016, p.113) model pembelajaran jigsaw ini bisa menjadi alternatif pemecahan masalah dengan langkah-langkah pembelajarannya yang sangat efektif dibandingkan dengan pembelajaran yang hanya menggunakan metode konvensional saja. Widiastini, dkk (2014, p.3) mengemukakan bahwa "Model pembelajaran Jigsaw merupakan salah satu model pembelajaran kooperatif yang bisa dikembangkan dalam pembelajaran Ilmu Pengetahuan Sosial untuk menumbuhkan keterlibatan siswa secara aktif dalam kegiatan pembelajaran.

Karena indikator keberhasilan dalam penelitian ini telah tercapai maka, hipotesis tindakan dalam penelitian ini telah tercapai yaitu penerapan model pembelajaran kooperatif tipe Jigsaw dapat meningkatkan hasil belajar siswa pokok bahasan Mengenal Benua di Kelas VI SD Negeri 1 Batuganda.

\section{Aktivitas Mengajar Guru}

Pada siklus I pertemuan pertama persentase aktivitas mengajar guru adalah $66,67 \%$ dan pertemuan kedua adalah $77,78 \%$ sedangkan pada siklus II persentase aktivitas mengajar guru mengalami peningkatan. Pada pertemuan pertama persentase aktivitas mengajar guru sebesar $88,89 \%$ dan pertemuan kedua sebesar $100 \%$.

Rendahnya persentase aktivitas mengajar guru pada siklus I diakibatkan oleh beberapa aktivitas guru dalam pembelajaran yang masih kurang seperti dalam memotivasi siswa untuk mengikuti pelajaran, membimbing siswa pada saat melakukan diskusi. Selain itu ditemukan aktivitas guru yang kurang memberi penguatan dan penghargaan kepada siswa yang memberikan pertanyaan/menaggapi pertanyaan dan kelompok yang kinerjanya bagus, sehingga berpengaruh terhadap aktivitas dan hasil belajar siswa. Hal ini sejalan dengan yang dikemukakan oleh Sanjaya (2006:148) bahwa guru dalam pembelajaran berperan sebagai fasilitator yaitu untuk memudahkan siswa dalam kegiatan pembelajaran. Guru berperan pula sebagai pengelola yaitu menciptakan iklim belajar yang memungkinkan siswa dapat belajar dengan nyaman.

\section{Aktivitas Belajar Siswa}

Pada siklus I pertemuan pertama persentase aktivitas belajar siswa adalah 66,67\% dan pertemuan kedua adalah 77,78\% sedangkan pada siklus II persentase aktivitas belajar siswa mengalami peningkatan. Pada pertemuan pertama persentase aktivitas belajar siswa sebesar $88,89 \%$ dan pertemuan kedua sebesar $100 \%$.

Rendahnya persentase aktivitas belajar siswa pada siklus I diakibatkan oleh beberapa aktivitas siswa dalam pembelajaran yang masih terbiasa dengan pola pembelajaran yang selama ini diterapkan oleh guru. Selain itu ditemukan aktivitas siswa dalam memberikan pertanyaan/menaggapi pertanyaan sehingga berpengaruh terhadap aktivitas dan hasil belajar siswa.

Aktivitas siswa dalam proses pembelajaran berdampak langsung terhadap pencapaian hasil belajar siswa setelah pembelajaran. Hal ini sesuai dengan yang dikemukakan oleh Winataputra (2007, p.72), bahwa hasil belajar tidak dapat dipisahkan dari apa yang terjadi 
dalam kegiatan belajar baik di kelas, di sekolah maupun di luar sekolah. Apa yang dialami oleh siswa dalam proses pengetahuan, kemampuannya merupakan apa yang diperolehnya. Pendapat tersebut juga serupa dengan yang dikemukakan oleh Dewei (1990 dalam Dimyati dan Mudjiono 2002, p.12) bahwa belajar yang baik, dilakukan oleh siswa yang aktif baik secara individual maupun secara kelompok.

Hasil evaluasi menunjukkan bahwa usaha dan keberhasilan belajar dipengaruhi oleh berbagai faktor yaitu faktor internal dan faktor eksternal. Hal ini sesuai dengan yang dikemukakan oleh Syah (2010, p.132) bahwa hasil belajar dipengaruhi oleh beberapa faktor yaitu, faktor internal adalah faktor yang berasal dari diri siswa, faktor eksternal adalah faktor yang berasal dari luar diri siswa dan faktor pendekatan belajar yaitu jenis upaya belajar yang meliputi strategi dan metode yang digunakan untuk melakukan pembelajaran.

\section{Simpulan}

1. Penerapan model pembelajaran kooperatif tipe jigsaw dapat meningkatkan hasil belajar IPS siswa pada materi Benua yang ada di dunia di kelas VI SD Negeri 1 Batuganda. Siklus I ketuntasan hasil belajar siswa mencapai $73,9 \%$ dan pada siklus II meningkat menjadi $91,3 \%$.

1. Penerapan model pembelajaran kooperatif tipe jigsaw dapat meningkatkan aktivitas mengajar guru pada materi benua yang ada di dunia di kelas VI SD Negeri 1 Batuganda. Persentase aktivitas mengajar guru pada siklus I pertemuan 01 mencapai $66,67 \%$ dan pertemuan 02 mencapai $77,78 \%$; sedangkan pada siklus II pertemuan 01 mencapai $88,89 \%$ dan pertemuan 02 mencapai $100 \%$.

2. Penerapan model pembelajaran kooperatif tipe jigsaw dapat meningkatkan aktivitas belajar siswa pada materi sumber daya alam di kelas IV SD Negeri 1 Batuganda. Persentase aktivitas belajar siswa pada siklus I pertemuan 01 mencapai $66,67 \%$ dan pertemuan 02 mencapai $77,78 \%$; sedangkan pada siklus II pertemuan 01 mencapai $88,89 \%$ dan pertemuan 02 mencapai $100 \%$.

\section{Referensi}

Alfazr. A.S., Diah Gusrayani, \& Sunarya, D.T. (2016). Penerapan Model Pembelajaran Jigsaw Untuk Meningkatkan Hasil Belajar Siswa Dalam Menemukan Kalimat Utama Pada Tiap Paragraf. Jurnal Pena Ilmiah: Vol. 1, No. 1. 111-120. https://ejournal.upi.edu/index.php/penailmiah/article/download/2937/1965

Bindiab, R.H., Marungkil, P. \& Rede, A. (2013). Penerapan Model Pembelajaran Kooperatif Tipe Jigsaw pada Pokok Bahasan Perubahan Wujud Benda untuk Meningkatkan Hasil Belajar Siswa SDN 2 Uebone. Jurnal Kreatif Tadulako Online Vol. 1 No. 2, 107-117. http://jurnal.untad.ac.id/jurnal/index.php/JKTO/article/download/2676/1793

Kurniyati, D. (2016). Peningkatan Hasil Belajar IPS Dengan Menerapkan Model Pembelajaran Quantum Teaching Di SDN Balong. Jurnal Pendidikan Guru Sekolah Dasar Edisi 4 Tahun Ke-5. 324-333. http://journal.student.uny.ac.id/ojs/ojs/index.php/pgsd/article/download/954/869

Mana'a, S. Bonifasius Saneba, dan Anthonius Palimbong. (2014). Meningkatkan Hasil Belajar Siswa Pada Pembelajaran IPS Dengan Menggunakan Pembelajaran Koperatif Tipe Numbered Heads Together di Kelas IV SDN Lalong Kecamatan 
Tinangkung Utara Kabupaten Banggai Kepulauan. Jurnal Kreatif Tadulako Online $\begin{array}{lllll}\text { Vol. } & 3 & \text { No. } & 3 . & 1-12 .\end{array}$ http://jurnal.untad.ac.id/jurnal/index.php/JKTO/article/download/3194/2256

Purwati. (2015). Meningkatkan Hasil Pemahaman Siswa Melalui Model Cooperatif Learning Tipe Jigsaw Pada Pembelajaran IPS Di Kelas IV SDN No. 1 Bonemarawa Kecamatan Rio Pakava Kabupaten Donggala. Jurnal Kreatif Tadulako Online Vol. 3 No. 4 , 174-184. http://jurnal.untad.ac.id/jurnal/index.php/JKTO/article/download/3076/2149

Rohani. (2004). Metode Pengelolaan Pembelajaran. Jakarta: Rineka Cipta.

Romianti, (2012). Meningkatkan Hasil Belajar Ilmu Pengetahuan Sosial (IPS) Melalui Model Pembelajaran Kooperatif Tipe Jigsaw Pada Siswa Kelas VI SDN 17 Napabalano Kecamatan Towea Kabupaten Muna. Skripsi. Kendari: FKIP. Universitas Halu Oleo Kendari

Slameto. (2003). Belajar dan Faktor-Faktor yang Mempengaruhinya. Rineka Cipta. Jakarta.

Sulasmi. (2011). Penerapan Model Pembelajaran Kooperatif Tipe Jigsaw untuk Meningkatkan Hasil Belajar IPS Siswa pada Materi Sumber Daya Alam di Kelas VI SDN 15 Katobu Kabupaten Muna. Skripsi. Kendari: FKIP. Universitas Halu Oleo Kendari.

Suparno. (2008). Teori Perkembangan Kognitif Jean Piaget. Kanisius: Yogyakarta.

Syah M. (2010). Pisikologi Pendidikan Dengan Pendekatan Baru. Bandung: PT. Remaja Rosdakarya.

Ulfah, K.R., Anang Santoso, Utaya, Sugeng. (2016). Hubungan Motivasi Dengan Hasil Belajar IPS. Jurnal Pendidikan: Teori, Penelitian, dan Pengembangan Volume: 1 Nomor: 8 Bulan Agustus Tahun 2016 Halaman: 1607-1611 http://journal.um.ac.id/index.php/jptpp/article/view/6678/2885

Untari. Y.A. (2013). Peningkatan Hasil Belajar IPS Siswa Kelas V Melalui Metode Simulasi Improved Results of IPS Learning Student Class V through Simulation Method. Psikopedagogia Jumal Bimbingan dan Konseling. Vol. 2, No. 2. 78-84. http://journal.uad.ac.id/index.php/PSIKOPEDAGOGIA/article/view/2574/2792

Widiastini, M., Kusmariyatni, N. \& Arini, NW. (2014). Keefektifan Model Pembelajaran Kooperatif Tipe Jigsaw Untuk Meningkatkan Hasil Belajar IPS Siswa Kelas V. Journal Mimbar PGSD Universitas Pendidikan Ganesha, Jurusan PGSD Vol: 2 No: 1 , 1-10. https://ejournal.undiksha.ac.id/index.php/JJPGSD/article/download/2033/1773 